\title{
EVIDENCE OF PREFERENTIAL FEMALE PREVALENCE OF HTLV-I ASSOCIATED TROPICAL SPASTIC PARAPARESIS IN BAHIA-BRAZIL
}

\author{
O. A. MORENO-CARVALHO * - J.I. SANTOS**-G. DI CREDICO* \\ B. GALVAO-CASTRO **
}

SUMMARY - In order to evaluate the prevalence of HTLV-I infection and its association with tropical spastic paraparesis (TSP) in Bahia, a Northeastern State of Brazil, CSF and sera from TSP patients and CSF and/or sera from some selected groups of individuals were studied. The results seem to indicate a higher prevalence of HTLV-I infection in women than men with TSP and among individuals of HIV risk groups. Some alterations of routine analysis of CSF can suggest HTLV-I infection in TSP patients.

KEY WORDS: tropical spastic paraparesis, HTLV-I antibodies, female prevalence.

Evidência de maior prevalência de paraparesia assuciada a infecç̃o pelo HTLV-I em mulho res na Bahia.

RESUMO - Com o objetivo de avaliar a prevalência de infecç̃o pelo HTLV-I e sua associação a paraparesia espática tropical na Bahia, foram estudadas amostras de líquido céfalorraqueano (LCR) e/ou soro de pacientes com esta doença e de outros grupos de indivíduos. Os resultados indicam que mulheres são mais afetadas pela doença associada à infecção pelo HTLV-I que os homens. Algumas alterações do exame do LCR podem sugerir infecção pelo HTLV-I em pacientes com paraparesia espática tropical.

PALAVRAS-CHAVE: paraparesia espástica tropical, HTLV-I anticorpos, prevalência em mulheres.

Tropical spastic paraparesis (TSP) has been observed in tropical regions of the world 2,4 . It is characterized as a chronic condition with gradual onset, in which progression is slow and indolent, sometimes reaching a plateau for periods of several years, during which patients experience mainly weakness of the legs and neurological examination shows spastic paraparesis with hyperreflexia 4. HTLV-I is a retrovirus, which has been associated with some kinds of leukemias and lymphomas since 19776 . In 1985, it was established an association between HTLV-I infection and TSP 3 . In Brazil, a tropical country, antibodies to HTLV-I have already been reported in TSP patients 5. In Bahia, a Northeastern State of Brazil, which has a mixed population of African and Portuguese descent, some TSP cases have been diagnosed without an identified etiologic agent, up to this point.

The purpose of this study was to evaluate the prevalence of HTLV-I infection in patients with TSP, comparing with the prevalence of HTLV-I infection in other groups of individuals.

\footnotetext{
* Fundação José Silveira - LCR: Laboratório Especializado em Líquido Cefalorraqueano; ** Lasp - Fiocruz - WHO Collaborating Center on Aids.

Dr. Otavio Augusto Moreno de Carvalho - Rua Praguer Frbes 89, apto. 101 - 40130 Salvador $B A$ - Brasil.
} 


\section{PATIENTS AND METHODS}

The cerebrospinal fluid (CSF) and sera from TSP patients and CSF and/or sera from selected groups were screened by HTLV-I ELISA (HTLV-I EIA, Genetic System, Seatle, USA) and confirmed to be positive by HTLV-I Western blot (Pageblot HTLV-I, Genetic System, Seatle, USA).' The HTLV-I positive patients were also tested for HIV1/HIV-2 antibodies by ELISA (Table 1).

Table 1. HTLV-I prevalence. Bahia, Bnazil.

\begin{tabular}{|c|c|c|c|c|}
\hline $\begin{array}{l}\text { GROUP } \\
\text { Tropical spastic paraparesis } \\
\text { Spouses of TSP patients }\end{array}$ & $\begin{array}{l}\text { FEMALE } \\
13 / 14+\end{array}$ & $\begin{array}{r}\text { MALE } \\
3 / 14 \\
3 / 3\end{array}$ & UNKNOWN & $\begin{array}{r}\text { TOTAL } \\
16 / 28 \\
3 / 3\end{array}$ \\
\hline Other neuropathies with legs involvement "• & $1 / 13$ & $0 / 23$ & & $1 / 36$ \\
\hline Headache patients & $0 / 16$ & $0 / 10$ & & $0 / 26$ \\
\hline Prisioners & & $5 / 64$ & & $5 / 64$ \\
\hline Healthy adult individuals & & $0 / 96$ & & $0 / 96$ \\
\hline Pregnant women & $1 / 99$ & & & $1 / 99$ \\
\hline HIV positive blood donors & & & $2 / 15$ & $2 / 15$ \\
\hline Total & $15 / 142$ & $11 / 210$ & $2 / 15$ & $28 / 367$ \\
\hline $\begin{array}{l}\text { - CSF and sora tested } \\
\text { + HTLV . I positive / number tested } \\
\text { - Other nquropathies: multiple scierosis, Guillain-E. } \\
\text { S. manseni myeloradiculitis, mvelooathies of unk }\end{array}$ & ntipar & & & \\
\hline
\end{tabular}

The patients with TSP and other myelopathies had a questionary filled with clinical data. The group of TSP was composed by patients who fulfilled the definition mentioned.

In CSF samples patterns considered were: cytology (cells/mm3 number and cytomorphological profile), protein and glucose concentrations (mg/dl), and gamma globulins content (\%). Specific antibodies to syphilis, cysticercosis, toxoplasmosis, schistosomiasis, HIV-1, HIV-2 were searched also.

\section{RESULTS}

The results shown in Table 1 suggest a higher prevalence of HTLV-I-associated TSP in womem (13/14). than in men $(3 / 14)$. Just one case was positive in the group of other myelopathies. This patient is a 67-year-old woman who said that she slep healthy and woke up severely sick (paresis and urinary impairment). The sera of three TSP paients husbands were

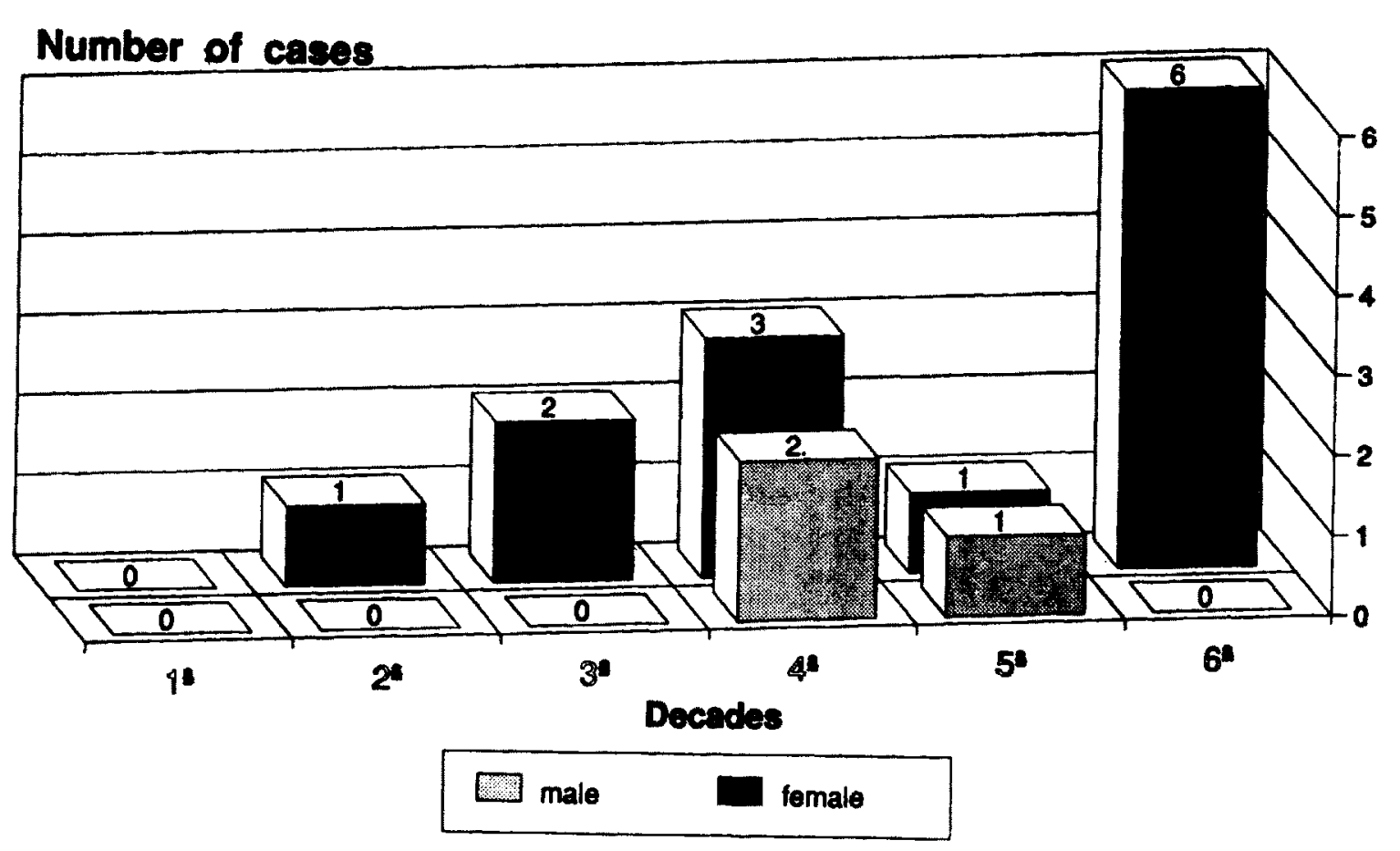

(35 - 47) $M=39 \quad(18-56) M=48$

Fig. 1. Tropical spastic paraparesis / HTLV-I positive: distribution of age. 
By comparing the CSF exams of TSP patients, HTLV-I positive with HTLV-I negative, we could observe some differences: slight to moderate increase of cell number (Fig. 4), slight to moderate increase of gamma globulins content (Fig. 5), and presence of plasma cells and eventually of eosinophils (Fig. 6) in patients HTLV-I positive. Nevertheless, the general pattern of proteins was altered in both groups (Fig. 7).

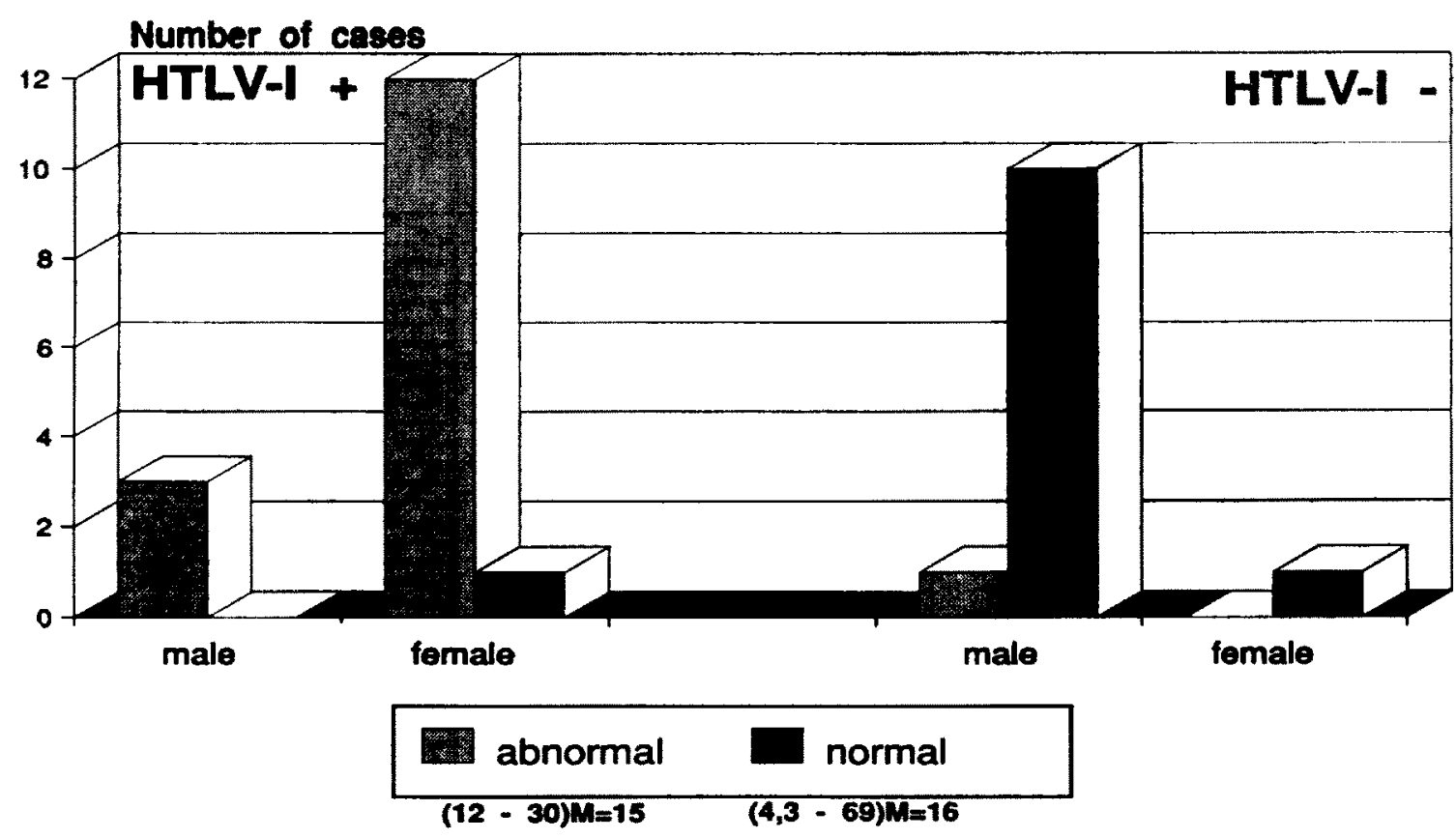

Fig. 4. Tropical spastic paraparesis: CSF total cell number.

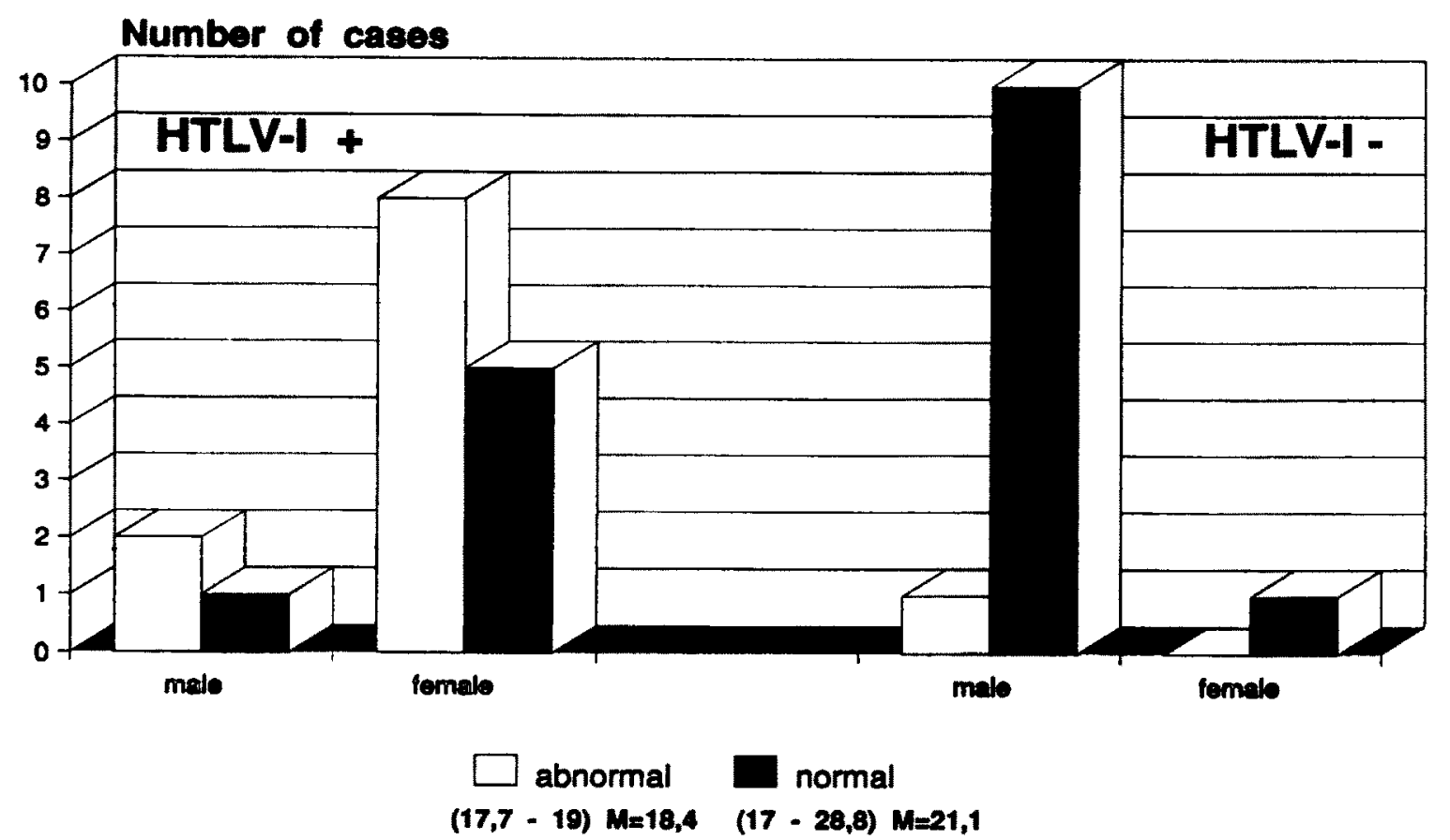

Fig. 5. Tropical spastic paraparesis: CSF gamma globulins.

\section{COMMENTS}

HTLV-I is a retrovirus implicated in the generation of some kinds of leukemias, lymphomas and TSP. It is transmitted from mother to child, by sexual contact from male to female and male to male, by blood transfusion, and by contaminated needles. Up to this point, TSP cases have been diagnosed in Bahia without an identified etiologic agent. We could observe in this study a preferential female prevalence of HTLV-I-associated tropical spastic paraparesis. This has already been observed in other regions of the world 1,7 . 
positive.' There was no positive case in the groups of headache patients and healthy individuals. Among 99 pregnant women, one was positive. In HIV risk groups we could observe a higher prevalence of HTLV-I antibodies comparing with the other groups, except the TSP groups.

By analysing the group of TSP patients, the majority of patients of both sexes were between the fourth and sixth decade of life and were mulattoes (Fig. 1 and Fig. 2). The period of evolution ranged from 6 months to more than 8 years and the medians were 5 years for men and 2 years for women (Fig. 3).

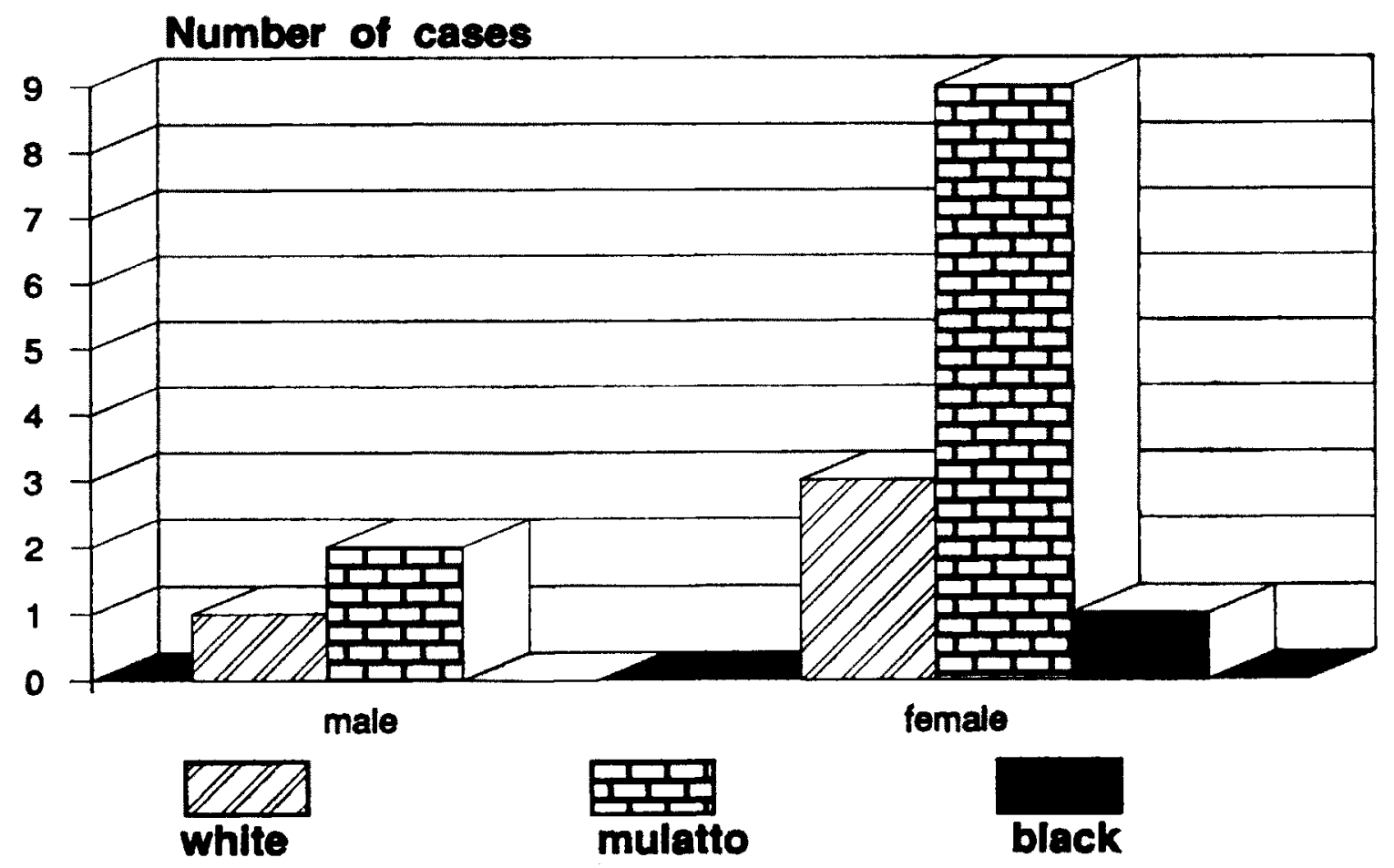

Fig. 2. Tropical spastic paraparesis / HTLV-I positive racial groups.

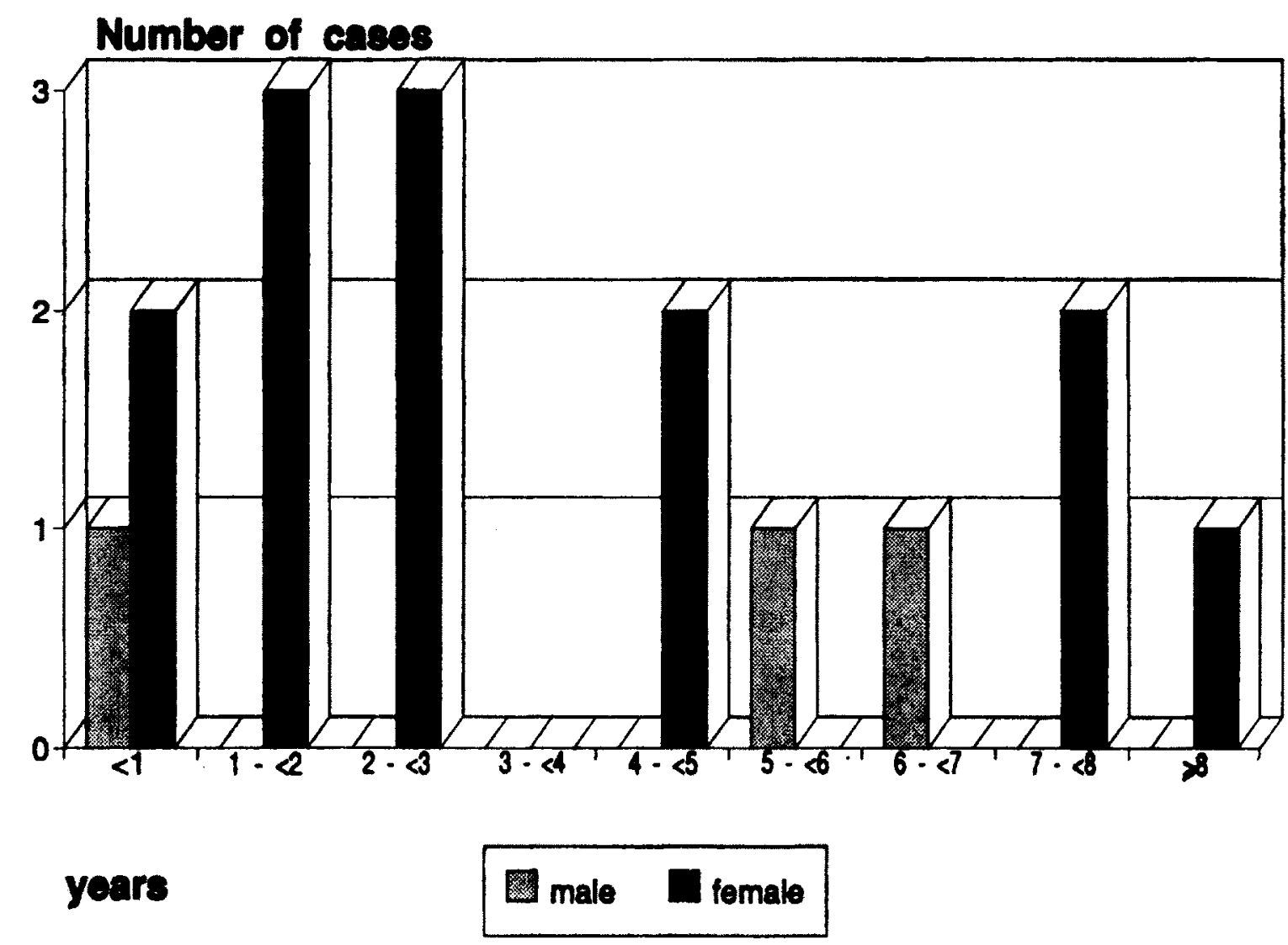

Fig. 3. Tropical spastic paraparesis / HTLV-I positive: period of evolution. 


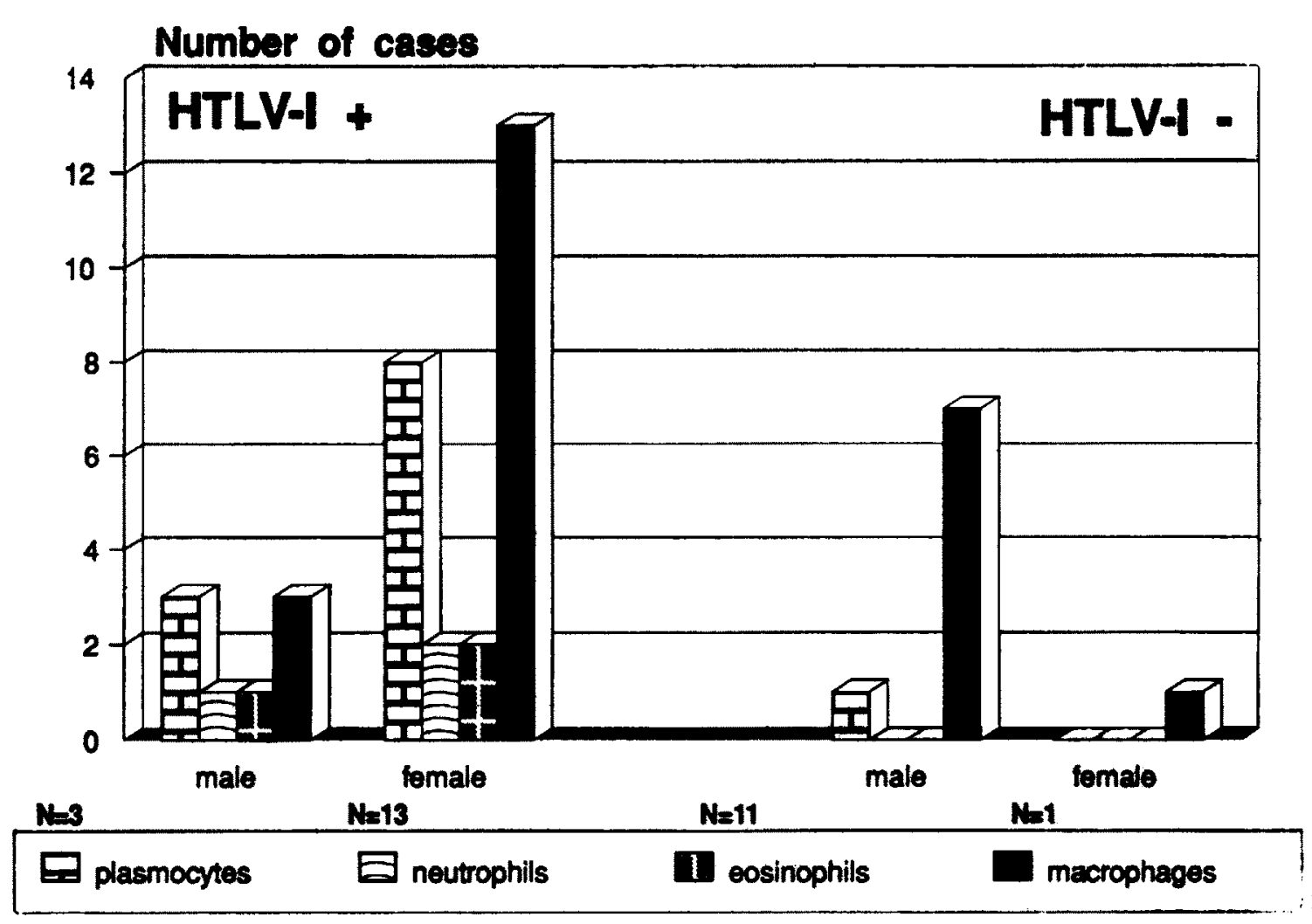

Fig. 6. Tropical spastic paraparesis: CSF specific cell count.

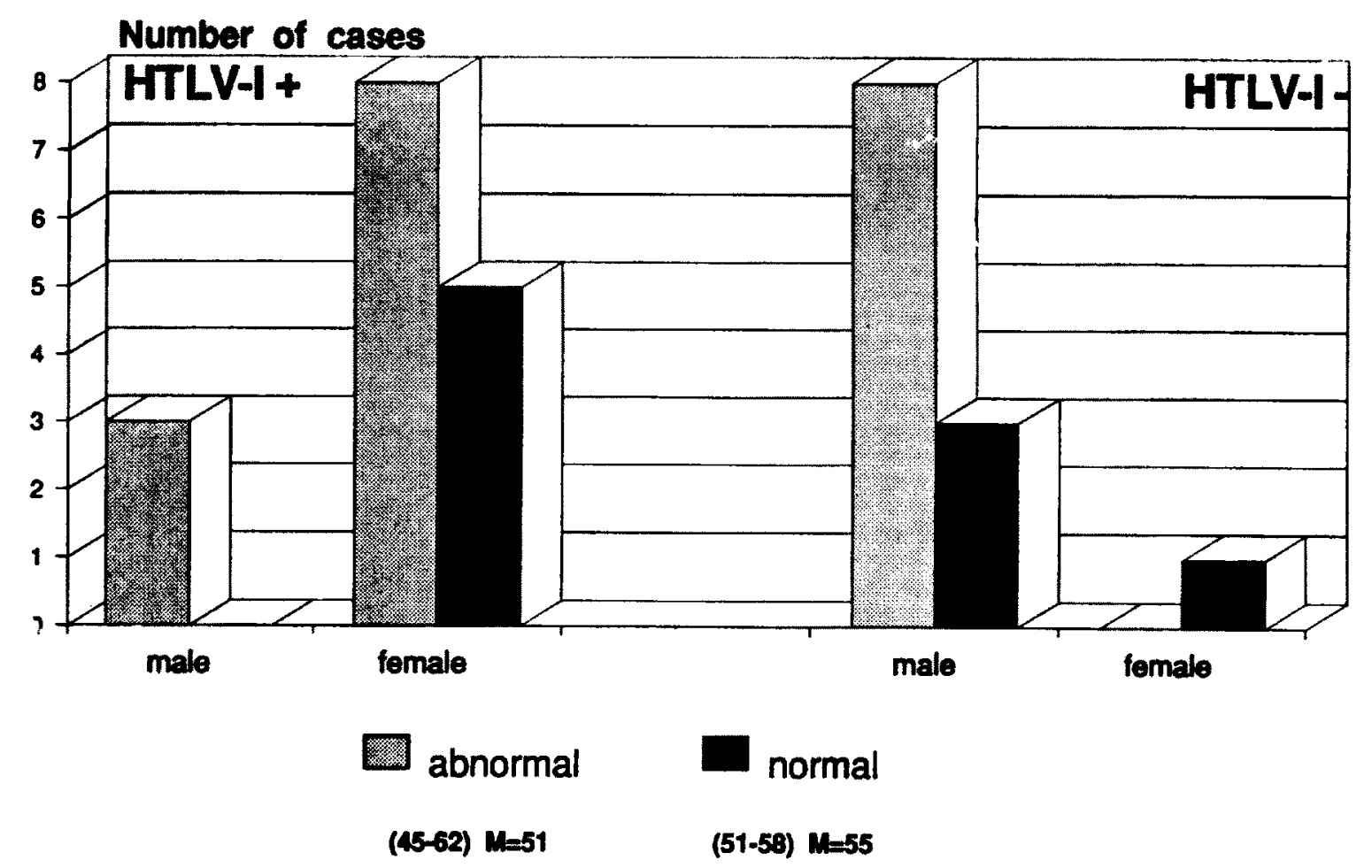

Fig. \%. Tropical spastic paraparesis: CSF total proteins.

Patients with HTLV-I-associated TSP show slight to moderate pleocytosis, plasma cells and eventually eosinophils and increased gamma globulins participation in CSF analysis when compared with HTLV-I-not-associated TSP patients. This HTLV-I related CSF pattern has already been reported 5 .

No evidence of antibodies to T.pallidum, S. mansoni, T. gondii, C. cellulosae, HIV-1 and HIV-2 was found in TSP patients.

We conclude that HTLV-I is an important agent of TSP in Bahia, seemingly with higher prevalence in women than men and some alterations of routine analysis of CSF can suggest HTLV-I infection in patients with TSP. In addition there are 
indications of a low prevalence in general population, whereas it was observed a higher prevalence in individuals in HIV risk groups.

We were not able to determine the cause of «HTLV-I-not-associated TSP». It is necessary to study a large number of TSP cases in order to avoid bias in TSP patients ascertainment.

\section{REFERENCES}

1. Cartier-Rovirosa L, Mora G, Araya F, Castilho J, Verdugo R, Miller MA, GajdusekDC, Gibbs CJ Jr. HTLV-I positive spastic paraparesis in a temperate zone. Lancet 1989, $1: 556-557$.

2. Garruto RM, Yanagihara R, Asher DM. Seroepidemiologia del virus HTLV-I en el Pacifico occidental. In Zaninovic V(ed): Retrovirus Humanos: HTLV-I, Paraparesia Espatica y Linfomas. Cali: Feriva Editores, 1989.

3. Jessain A, Vernant JC, Maurs L, Barin F, Gout O. Antibodies to human H-lymphotropic virus type-I in patients with tropical spastic paraparesis. Lancet 1985, 2:407-409.

4. Roman GC: The neuroepidemiology of tropical spastic paraparesis. Ann Neurol 1988, 23(Suppl): $\$ 113-\$ 120$.

5. Spina-França A, Livramento JA, Machado LR, Gomes HR, Vianna LS, Castro LHM, Nobrega JPS, Bacheschi LA. HTLV-I antibodies in serum and CSF in tropical spastic paraparesis in Brazil. Arq Neuro-Psiquiat (São Paulo) 1990, 48:441-447.

6. Uchiyama $T$, Yodoi $J$, Sagawa $K$, Takatsuki $K$, Uchino $H$. Adult $T$-cell leukemia: clinical and hematologic features of 16 cases. Blood 1977, 50:481-492.

7. Vernant JC, Maurs L, Gersain A. HTLV-I-associated tropical spastic paraparesis in Martinique: a reappraisal. Ann Neurol 1988, 23(Suppl):S133-S135. 